\title{
Ceropegia khasiana (Apocynaceae: Ceropegieae), a new species from Meghalaya, Northeast India
}

\author{
M. Murugesan ${ }^{1,3}$, A.A. Mao ${ }^{1,4}$, L.R. Meitei ${ }^{1}$ \& S.S. Kambale ${ }^{2}$ \\ ${ }^{1}$ Botanical Survey of India, Eastern Regional Centre, Shillong, Meghalaya, India \\ taxonmurugesh@gmail.com \\ ${ }^{2}$ Department of Botany, Maratha Vidya Prasarak Samaj's Arts, \\ Commerce \& Science College, Tryambakeshwar- 422 212, Maharashtra, India \\ ${ }^{3}$ Present address: Botanical Survey of India, Southern Regional Centre, \\ Coimbatore, Tamil Nadu \\ ${ }^{4}$ Present address: Botanical Survey of India, Head Quarters, \\ Kolkata, West Bengal
}

\begin{abstract}
A new species of Ceropegia, Ceropegia khasiana Murug., A.A.Mao, Meitei \& Kambale (Apocynaceae), is described and illustrated from Meghalaya, Northeast India. The new species is superficially similar to Ceropegia macrantha Wight but it differs in having fewer, shorter fascicled roots up to $8 \mathrm{~cm}$ long, linear-lanceolate leaves with long acuminate apices, smaller flowers up to $4.7 \mathrm{~cm}$ long, 12-18-flowered inflorescences with two flowers open at a time, two umbels per node, corolla tube pinkish outside with dark reddish stripes, reddish inside in mature flowers, greenish or pinkish to reddish at the apex of corolla lobes which are densely ciliate hairy, inflated base with reddish patch at middle, outer corona with very sparse small ciliate hairs, and each pair of follicular mericarps unequal in length.
\end{abstract}

Keywords. Asia, Ceropegieae-Stapeliinae, Flora of India, Ri-Bhoi district

\section{Introduction}

The genus Ceropegia L. (Apocynaceae: Ceropegieae) has about 244 species distributed from southern Africa and around the perimeter of the Indian Ocean to Australia (Ansari, 1984; Bruyns, 1997, 2003; Jagtap \& Singh, 1999; Kambale \& Yadav, 2019; Kumar et al., 2018; Li et al., 1995; Mabberley, 2008; Manudev et al., 2016; Maurya et al., 2018; Punjani et al., 2017; Rahangdale \& Rahangdale, 2012; Sachin et al., 2006). The highest diversity in the genus Ceropegia occurs in South Africa, followed by Kenya, Madagascar and India (Sri Rama Murthy et al., 2012). The genus Ceropegia can be distinguished from other genera of Ceropegieae such as Caralluma R.Br. by the presence of root tubers, either as single large potato-like tubers or fascicled tuberous roots, and the distinctive cage-like structure of the flowers formed by the corolla lobes, which are apically connate to various degrees (Clarke, 1883; Huber, 1957; Ansari, 1984; Li et al., 1995; Meve, 2009; Kullayiswamy et al., 2013; Kidyoo \& Paliyavuth, 2017). Typically, the root system is species-specific. The genus exhibits tremendous diversity with respect to habit, habitat, flower architecture and ecological adaptations 
(Dyer, 1983; Bruyns, 1997; Kambale et al., 2012). The basally inflated corolla tube, lined with downwardly pointing hairs, forms a temporary trap for small flies and other insects and hence this group is popularly called the "fly trap flowers" (Masinde, 2004; Ollerton et al., 2009). Many species of this genus are narrow endemics and they are included in various IUCN Red Lists (Nayar \& Sastry, 1987-1989).

In India, the genus is represented by 69 taxa ( 62 species, two subspecies and five varieties) (Manudev et al., 2016; Kambale \& Yadav, 2019), of which 37 are endemic to Peninsular India (Ahmedullah \& Nayar, 1987; Kumar et al., 2018; Kambale \& Yadav, 2019). There are 11 species in the North-eastern region of India, viz., Ceropegia angustifolia Wight, C. arnottiana Wight, C. hookeri C.B.Clarke ex Hook.f., C. kachinensis Prain, C. longifolia Wall., C. lucida Wall., C. macrantha Wight, C. mizoramensis Ram.Kumar \& S.Sharma, C. murlensis Ram.Kumar \& S.Sharma, C. pubescens Wall. and $C$. wallichii Wight. Of these, eight species are in Meghalaya (Jagtap \& Singh, 1999).

During a botanical exploration to the Sumer forested areas in Ri-Bhoi district (Meghalaya) to collect plants for ex situ conservation projects, the authors collected an interesting species of Ceropegia. Five plants (flowering \& fruiting) were collected and grown in the Experimental Botanical Garden, Botanical Survey of India, Eastern Regional Centre, Barapani, Shillong. After examination of these plants, comparison to the relevant literature, and the study of herbarium material deposited in ARUN, ASSAM, BSHC, CAL, MH and further field surveys, we concluded that these materials did not match with any described species. Therefore, it is described here as a new species along with photographic illustrations (Fig. 1).

\section{Taxonomic treatment}

Ceropegia khasiana Murug., A.A. Mao, Meitei \& Kambale, sp. nov.

The new species is superficially similar to Ceropegia macrantha Wight but it differs in having fewer, shorter fascicled roots up to $8 \mathrm{~cm}$ long (see Table 1 for the character states in C. macrantha), linear-lanceolate leaves with long acuminate apices, smaller flowers up to $4.7 \mathrm{~cm}$ long, 12-18-flowered inflorescences with two flowers open at a time, two umbels per node, corolla tube pinkish outside with dark reddish stripes, reddish inside in mature flower, greenish or pinkish to reddish at the apex of corolla lobes which are densely ciliate hairy, inflated base with reddish patch at middle, outer corona with very sparse small ciliate hairs and each pair of follicular mericarps unequal in length. - TYPE: India, Meghalaya, Ri-Bhoi District, Sumer forests of East Khasi Hills $\left(25^{\circ} 62^{\prime} 33.8^{\prime \prime} \mathrm{N}, 91^{\circ} 90^{\prime} 21.4^{\prime \prime} \mathrm{E}\right), 950$ m elevation, 10 July 2017, M. Murugesan 137313 (holotype ASSAM; isotypes MH). (Fig. 1).

Perennial, twining herb up to $4 \mathrm{~m}$ long. Stem wiry, slender, terete, pinkish, red-maroon or pale green, sparsely minutely hairy or rarely glabrous; internodes 7-25 cm long, 1-2 $\mathrm{mm}$ in diam. Roots 9-12, fascicled, fusiform, fleshy, short, up to $8 \mathrm{~cm}$ long, 2-5 mm in diam. Leaves simple, opposite, decussate, petiolate, lanceolate or linear-lanceolate, 


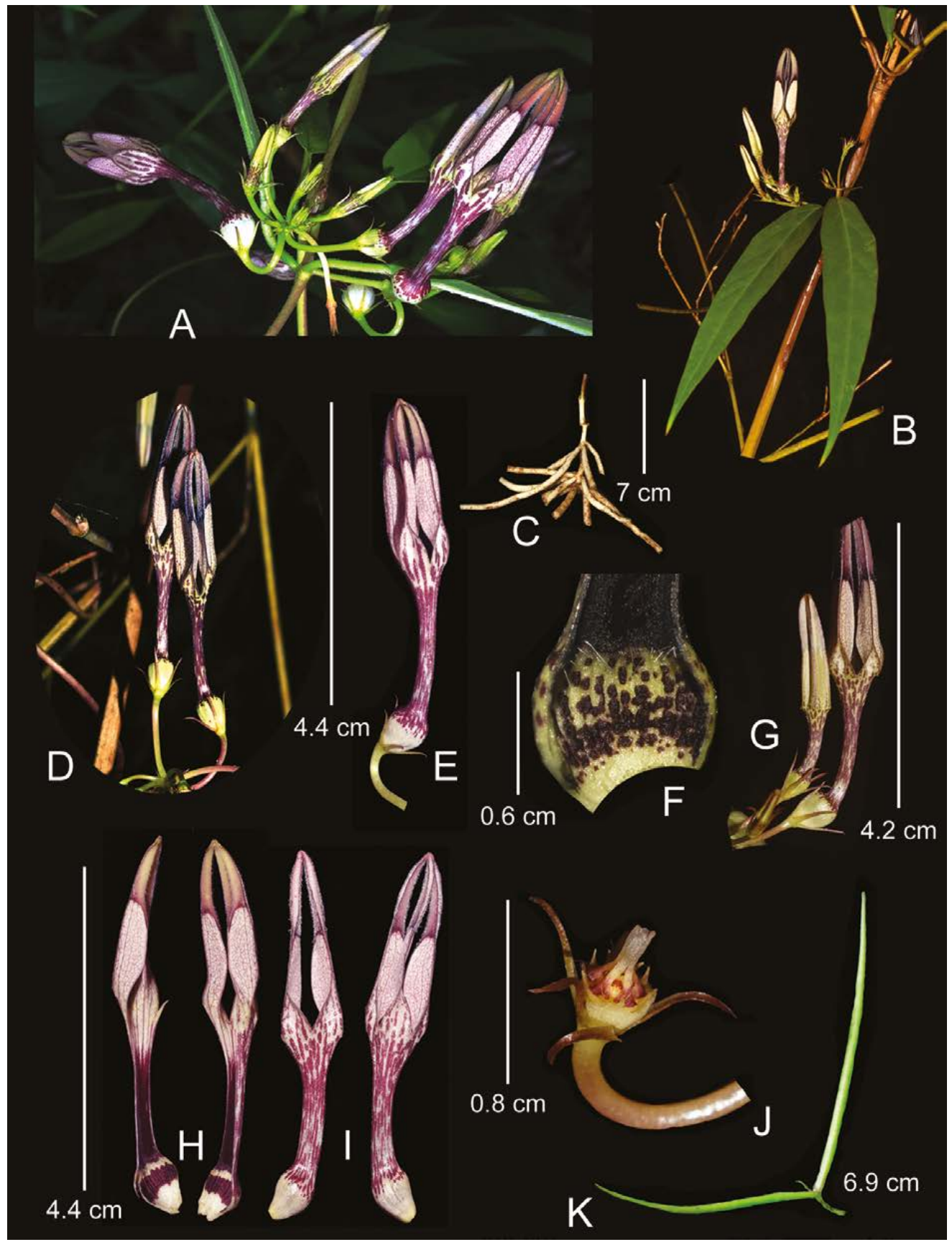

Fig.1. Ceropegia khasiana Murug. et al. A. Habit. B. Plant from ex-situ conservation collection. C. Fascicled roots. D. \& E. Mature flowers. F. L.S. of young flower showing hairs. G. Young flowers. H. Ventral view of flowers. I. Dorsal view of flowers. J. Corona. K. Mericarp. (Photos: M. Murugesan). 
Table 1. Major differences between Ceropegia khasiana Murug. et al. and its closely allied species Ceropegia macrantha Wight.

\begin{tabular}{|c|c|c|}
\hline Characters & Ceropegia khasiana sp. nov. & Ceropegia macrantha Wight \\
\hline Fascicled roots & Few, up to $8 \mathrm{~cm}$ long & Many, up to $18 \mathrm{~cm}$ long \\
\hline Leaves & $\begin{array}{l}\text { Linear-lanceolate, long acuminate at } \\
\text { apex }\end{array}$ & $\begin{array}{l}\text { Ovate-lanceolate or elliptic- } \\
\text { lanceolate, short obtusely acuminate } \\
\text { at apex }\end{array}$ \\
\hline Inflorescence & $\begin{array}{l}\text { Umbels } 2 \text { per node, } 12-18 \text {-flowered, } \\
\text { two flowers open at a time in an } \\
\text { umbel }\end{array}$ & $\begin{array}{l}\text { Umbel } 1 \text { per node, } 4-10 \text {-flowered, } \\
\text { only one flower open at a time in an } \\
\text { umbel }\end{array}$ \\
\hline Flowers & Smaller, 4-4.7 cm long & Larger, $5.2-6.5 \mathrm{~cm}$ long \\
\hline Corolla tube & $\begin{array}{l}1.5-2 \mathrm{~cm} \text { long, } 2-4 \mathrm{~mm} \text { in diam., } \\
\text { purplish maroon streaked and } \\
\text { blotched with pinkish white on outer } \\
\text { surface, reddish maroon on inner } \\
\text { surface except at the tip of corolla } \\
\text { tube, pinkish white with red lines } \\
\text { towards top }\end{array}$ & $\begin{array}{l}2.5-3.5 \mathrm{~cm} \text { long, } 3-6 \mathrm{~mm} \text { in diam., } \\
\text { greenish white with purplish maroon } \\
\text { streaks and blotches on outer surface, } \\
\text { black purple within }\end{array}$ \\
\hline Corolla lobes & $\begin{array}{l}\text { Up to } 2.2 \mathrm{~cm} \text { long; base pinkish with } \\
\text { reddish reticulate veins inside and } \\
\text { pinkish white and purplish maroon } \\
\text { streaked and blotched outside; } \\
\text { pinkish or maroon towards apex, } \\
\text { minute ciliate hairy within }\end{array}$ & $\begin{array}{l}\text { Up to } 3.5 \mathrm{~cm} \text { long; mottled purple- } \\
\text { maroon above, with dense brown- } \\
\text { black, long ciliate hairy within }\end{array}$ \\
\hline $\begin{array}{l}\text { Dilated base of } \\
\text { corolla tube }\end{array}$ & $\begin{array}{l}\text { Pink blotched at middle, pinkish or } \\
\text { greenish white at base and apex }\end{array}$ & $\begin{array}{l}\text { Prominently rugose, maroon-brown } \\
\text { vertical stripes within, greenish white } \\
\text { in between the vertical stripes }\end{array}$ \\
\hline $\begin{array}{l}\text { Inner corona } \\
\text { lobes }\end{array}$ & Equal in length, smaller & Unequal in length, longer \\
\hline $\begin{array}{l}\text { Outer corona } \\
\text { lobes }\end{array}$ & Very sparse minutely ciliate hairy & Densely 5-7 mm long ciliate hairy \\
\hline Pollinia & Yellowish & Brownish \\
\hline $\begin{array}{l}\text { Follicular } \\
\text { Mericarps }\end{array}$ & Unequal in length & Equal in length \\
\hline
\end{tabular}

5-15 $\times 0.5-2 \mathrm{~cm}$, slightly attenuate or cuneate at base, acute-acuminate at apex, entire at margins, minutely pubescent hairy on adaxial surface and along the margins, abaxially glabrous, except on nerves; petiole up to $1.5 \mathrm{~cm}$ long, $1.2-2.2 \mathrm{~mm}$ in diam., channelled above, with sparse row of hairs, rarely glaucous. Inflorescences of extraaxillary umbellate cymes, 12-18-flowered, two flowers open at a time; peduncles extra-axillary, two per node, $1-2.5 \mathrm{~cm}$ long, $1.2-1.8 \mathrm{~mm}$ in diam., sparsely pubescent hairy, greenish-pinkish; pedicels $1-1.5 \mathrm{~cm}$ long, $1-1.2 \mathrm{~mm}$ in diam., greenish-pinkish; bracts 1 or 2 at base of pedicel, lanceolate, 1.5-2 mm long, greenish-pinkish, acute at apex, hairy at margins, caducous. Calyx 5-partite, greenish at base, pinkish towards apex; lobes 5-7 × 0.6-0.9 mm, linear-lanceolate, acute-acuminate at apex, greenish- 
pinkish. Corolla $4-4.7 \mathrm{~cm}$ long, sparsely minutely hairy outside at base, dense towards apex, glabrous within; corolla tube 1.5-2 cm long, 2-4 $\mathrm{mm}$ in diam., purplish maroon streaked and blotched with pinkish white on outer surface, reddish maroon on inner surface except at the tip of corolla tube, pinkish white with red lines towards top; inflated base 5-7 $\times 5.5-8 \mathrm{~mm}$, pinkish white, streaked and blotched purplish maroon at apex on outer surface; inner surface greenish white to pinkish white with reddish or purplish maroon blotch at middle and a ring of downwardly pointed hairs at the throat; lobes $5,2-2.2 \times 0.6-0.7 \mathrm{~cm}$, lanceolate or ovate-lanceolate, folded, keeled, pinkish at base with clear reddish reticulate veins inside, pinkish white, streaked and blotched purplish maroon outside, apical part slender, pinkish reddish, coherent at apex, keeled, ciliate hairy within, glabrous without. Corona biseriate; outer with five bifid lobes, 1-1.2 mm long, each lobe very sparsely ciliate, hairs 1-1.5 mm long; inner lobes linear-lanceolate, 2-2.5 mm long, reddish-pinkish at base, translucent yellowish white towards apex, rounded or obtuse at apex, glabrous. Pollinia yellowish, ovoid, with pellucid margin, $0.25-0.4 \times 0.2-0.35 \mathrm{~mm}$, caudicles short, c. $0.25 \mathrm{~mm}$ long, corpusculum clavate, minute, $0.2-0.3 \mathrm{~mm}$ long, reddish to brownish. Ovary conical, c. $2 \times 0.5 \mathrm{~mm}$, glabrous. Follicular mericarps in unequal pairs, up to $10 \mathrm{~cm}$ long, straight or slightly curved above the middle, erect, tapering at both ends, blunt at tips, glabrous. Seeds up to $7 \times 1 \mathrm{~mm}$; brownish, comose; coma up to $2.5 \mathrm{~cm}$ long, silky white.

Distribution. So far known only from Sumer forest areas, Ri-Bhoi district of Meghalaya India.

Ecology. Occasional along forest margins at an altitudinal range between 900-950 $\mathrm{m}$ above sea level. A total of six mature individuals were located at the type locality. The species grows in association with Arundinella nepalensis Trin., Ceropegia sp., Crotalaria assamica Benth., Eulophia pauciflora Guillaumin and Ischaemum spp.

Phenology. Flowering: July-August. Fruiting: August-October.

Etymology. The new species is named after the type locality, Khasi hills, Meghalaya.

Provisional IUCN conservation assessment. The new species is currently known only from the type locality. During the field surveys we have located only six mature individuals within this forest which covers an area of $3 \mathrm{~km}^{2}$. The species is assessed here using IUCN Red List Categories and Criteria version 3.1 (IUCN, 2017) as Critically Endangered CR B1ab(iii), B2ab(iii). Habitat destruction caused by wild fires, mining, collection of Minor Forest Produces (MFP) by local people, fire wood collection and cattle grazing were determined as the major threats during the study period. Extensive explorations to similar habitats and micro environments in the adjacent localities are required to assess its whether there are as-yet unknown populations in other parts of Northeast India.

Taxonomic notes. Ceropegia khasiana is a member of the Ceropegia longifolia complex. 
This complex includes Ceropegia longifolia, C. longifolia subsp. sinensis H.Huber var. sinensis H.Huber, C. macrantha, C. mizoramensis and C. murlensis (Kumar et al., 2018). Species from this complex have fleshy swollen roots. The approximately equal length of the corolla lobes and tubes is a character shared by Ceropegia khasiana and C. longifolia subsp. sinensis var. sinensis. The corolla lobes in the latter are ovate and have long, pendulous white-coloured trichomes and in the former the lobes are linearlanceolate and pilose-pubescent within.

ACKNOWLEDGEMENTS. The authors are grateful to the Director, Botanical Survey of India, Kolkata, for facilities and encouragement. We are also thankful to Dr S.K. Singh, Scientist-D \& Head of office, BSI, ERC, Shillong and Dr C. Murugan Scientist-D \& Head of office, BSI, SRC, Coimbatore for their kind help and support. The authors are also thankful to Mr Chalbasson Lyngwa and Mr Evenstone Wahlang, JPFs for their kind help during field work. SSK thanks the Principal, Arts, Commerce and Science College, Tryambakeshwar for laboratory facilities.

\section{References}

Ahmedullah, M. \& Nayar, M.P. (1987). Endemic Plants of the Indian Region. Kolkata: Botanical Survey of India.

Ansari, M.Y. (1984). Fascicles of Flora of India, fasc. 16, Asclepiadaceae: Genus Ceropegia. Kolkata: Botanical Survey of India.

Bruyns, P.V. (1997). A note on Ceropegia L. (Asclepiadaceae) of Silent Valley, Kerala, India. Rheedea 7: 107-114.

Bruyns, P.V. (2003). Three new succulent species of Apocynaceae (Asclepiadoideae) from southern Africa. Kew Bull. 58: 427-435.

Clarke, C.B. (1883). Asclepiadaceae. In: Hooker, J.D. (ed.) The Flora of British India, vol. 4, pp. 66-75. London: Reeve \& Co.

Dyer, R.A. (1983). Ceropegia, Brachystelma and Riocreuxia in Southern Africa. Rotterdam, Netherlands: A.A. Balkema publishers.

Huber, H. (1957). Revision der Gattung Ceropegia. Memórias de Sociedade Broteriana, vol. 12. Coimbra: Instituto Botanicoda Universidade de Coimbra.

IUCN (2017). The IUCN Red List of Threatened Species: Version 2017-3. Cambridge UK: IUCN. Available from http://www.iucnredlist.org/

Jagtap, A.P. \& Singh, N.P. (1999). Fascicles of Flora of India, fasc. 24, Asclepiadaceae and Periplocaceae. Kolkata: Botanical Survey of India.

Kambale, S.S., Chandore, A.N. \& Yadav, S.R. (2012). Ceropegia concanensis, a new species (Apocynaceae: Ceropegieae) from Western Ghats, India. Kew Bull. 67: 843-848.

Kambale, S.S. \& Yadav, S.R. (2019). Taxonomic revision of Ceropegia (Apocynaceae: Ceropegieae) in India. Rheedea 29(1): 01-115.

Kidyoo, M. \& Paliyavuth, C. (2017). Ceropegia digitiformis sp. nov. (Apocynaceae, Asclepiadoideae) from Northeastern Thailand. Taiwania 62(1): 24-28.

Kullayiswamy, K.R., Sandhyarani, S. \& Karuppusamy, S. (2013). Ceropegia pullaiahii sp. nov. (Apocynaceae, Asclepiadoideae) from India. Nordic J. Bot. 31(2): 166-169. 
Kumar, R., Sharma, S. \& Dwivedi, M.D. (2018). Ceropegia mizoramensis and C. murlensis (Asclepiadaceae) - Two new species from Northeast India with phylogenetic and morphological evidence support. Taiwania 63(2): 163-170.

Li, P.T., Gilbert, M.G. \& Stevens, W.D. (1995). Asclepiadaceae. In: Wu, Z.Y. \& Raven, P.H. (eds) Flora of China, vol. 16, pp. 189-270. Beijing: Science Press; and St. Louis: Missouri Botanical Garden Press.

Mabberley, D.J. (2008). Mabberley's Plant-Book: A portable dictionary of plants, their classification and uses, 3rd ed. Cambridge, UK: Cambridge University Press.

Manudev, K.M., Kambale, S.S., Pramod, C. \& Prakash, P.S. (2016). A new species of Ceropegia (Apocynaceae: Ceropegieae) from a midland lateritic hill of Kerala, India. Int. J. Advanced Res. 4 (5): 1408-1414.

Maurya, R.R., Qureshimatva, U.M., Gamit, S.B. \& Solanki, H.A. (2018). New Record to the Flora of Gujarat, India: Ceropegia vincaefolia Hook. (Family Asclapidaceae). Indian Forester 144(1): 101.

Masinde, P.S. (2004). Trap-flower fly pollination in East African Ceropegia L. (Apocynaceae). Int. J. Trop. Insect Sci. 24: 55-72.

Meve, U. (2009). Ceropegia thailandica (Asclepiadoideae-Ceropegieae), a spectacular new Thai species. Bradleya 27: 161-164.

Nayar, M.P. \& Sastry, A.R.K. (1987-1989). Red Data Book of Indian plants, vols. I-III. Calcutta: Botanical Survey of India.

Ollerton, J., Masinde, S., Meve, U., Picker, M. \& Whittington, A.E. (2009). Fly pollination in Ceropegia (Apocynaceae: Asclepiadoideae): biogeographic and phylogenetic perspectives. Ann. Bot. 103: 1501-1514.

Punjani, B., Pandey, V., Desai, P. \& Patel, S. (2017). Ceropegia hirsuta Wight \& Arn. (Apocynaceae: Asclepiadoideae): A New Record to the Flora of Gujarat State, India. Indian Forester 143(1): 72-73.

Rahangdale, S.S. \& Rahangdale, S.R. (2012). Variety Novae of Ceropegia mahabalei Hemadri \& Ansari [Apocynaceae: Asclepiadoideae]. Indian Forester 138(2): 201-203.

Sachin, P., Suresh, J.D. \& Subhash, S.D. (2006). A new variety of Ceropegia oculata Hook. (Apocynaceae) from Satpuda hill ranges of Maharashtra, India. Curr. Sci. 91(9): 11421145.

Sri Rama Murthy, K., Kondamudi, R., Chandrasekhara Reddy, M., Karuppusamy, S. \& Pullaiah, T. (2012). Check-list and conservation strategies of the genus Ceropegia in India. Int. J. Biodivers. \& Conservation 4(8): 304-305. 
